\title{
Bats associated to caves in Jalisco, Mexico
}

\author{
Héctor Leonel Ayala Téllez ${ }^{1}$, luis Ignacio Iñiguez-Dávalos ${ }^{2 *}$, Miguel Olvera-Vargas² ${ }^{2}$ Jorge Albino Vargas-Contreras ${ }^{3}$ and Oralia Araceli \\ HERRERA-LIZAOLA ${ }^{4}$. \\ ${ }^{1}$ Doctorado en Biosistemática, Ecología y Manejo de Recursos Naturales y Agrícolas (BEMARENA), Universidad de Guadalajara. \\ Av. Independencia Nacional 151, CP. 48900, Autlán. Jalisco, México. E-mail: leonel@redudg.udg.mx (HLAT). \\ 2 Departamento de Ecología y Recursos Naturales - IMECBIO, Centro Universitario de la Costa Sur, Universidad de Guadalajara. Av. \\ Independencia Nacional 151, CP. 48900, Autlán. Jalisco, México. Email: liniguez@cucsur.udg.mx (LIID), molvera@cucsur.udg.mx (MOV). \\ ${ }^{3}$ Facultad de Ciencias Químico Biológicas, Universidad Autónoma de Campeche. Av. Agustín Melgar S/N Colonia Buenavista. CP. \\ 24036, San Francisco de Campeche. Campeche, México. Email: jalbino@hotmail.com (JAVC). \\ ${ }^{4}$ Sistema de Universidad Virtual, Universidad de Guadalajara. Av. Enrique Díaz de León 782, Col. Moderna, CP. 44190, Guadalajara. \\ Jalisco, México. Email: oraliaraceli@hotmail.com (OAHL) \\ * Corresponding author
}

Roost selection is important for bats, not only because roosts provide protection against predators but also because they provide stable environmental factors that can help them to optimize their physiological response and maintenance. For a high number of bat species, caves are an extremely important resource, sometimes housing a large number of individuals. In Jalisco, so far have been registered 72 species of bats, which equals $52 \%$ of the bats in the country. However, little is known about which species utilize caves as habitat, including the abundance of their populations. The aims of this study were: 1) to identify some of the main cave roosts for bats in the State of Jalisco, 2) to describe the richness and composition of bat ensembles associated to caves in Jalisco, and 3) to link the distribution of bats among the caves with some environmental factors. Using previous records and references, 21 caves with presence of bats were located and surveyed. We conducted bat captures to identify these species and for those individuals for which their capture was not possible, we used ultrasonic recordings. We estimated the number of individuals using different techniques. A Non-Metric Multidimensional Scaling analysis (NMDS) was used to determine if there is a spatial pattern relationship between bat species and caves. Also, a Canonical Correspondence Analysis (CCA) was conducted to explore which environmental variables explain the spatial pattern of distribution of bats recorded in this study. In the 21 surveyed caves, we found 23 bat species, accounting for $32 \%$ of the bat fauna in Jalisco (six species were identified using ultrasonic calls). The NMDS ordination analysis separated the species of bats in three main groups: one is associated to hot and humid caves, the second included species living in cool and dry caves, and a third group which was related to a cave of higher altitude, associated with temperate habitats. The CCA reported that temperature and humidity of the cave and the altitude as the most important variables for some groups of bats. The richness and abundance of bats were variable among caves and were associated to factors such as the intrinsic requirements of the species, physical conditions of the cave, and to the degree of human disturbance observed in each cave. The association of environmental variables and the presence and the number of bats was statistically significant, particularly with temperature and relative humidity in the case of hot caves, and with altitude for other species of bats. This work contributes to establish a baseline on the knowledge of the cave bats in the State of Jalisco. Some of the caves must be considered as priority for conservation, either for harbor a high number of individual or a high species richness.

Para los murciélagos la selección de refugios es importante, ya que de ellos depende la seguridad ante los depredadores, así como un ambiente estable en los factores ambientales como la temperatura y humedad, lo que les ayuda al desempeño óptimo de su fisiología. Las cuevas son uno de los recursos más importantes para muchas especies, algunas veces albergando gran número de individuos. En Jalisco se han registrado 72 especies de quirópteros. Sin embargo aún se desconoce cuáles especies de murciélagos habitan en las cuevas, así como en qué situación se encuentran sus poblaciones. El objetivo de este trabajo fue el identificar las principales cuevas con murciélagos en Jalisco. Describir la riqueza y composición de especies de ensambles de quirópteros asociados a cuevas en Jalisco, y vincular la distribución de los murciélagos en las cuevas con algunas variables ambientales. Se utilizaron registros de campo y literatura con lo que se localizaron y se muestrearon 21 cuevas. Las especies se identificaron por muestreo directo en las cuevas y por grabaciones de ultrasonido donde no fue posible su captura. Se estimó el número de individuos por diferentes métodos. Se aplicó un escalamiento multidimensional no-métrico (NMDS) para establecer si los murciélagos encontrados en las 21 cuevas presentan un patrón de distribución espacial determinado. Después se realizó un análisis de correspondencia canónica (CCA) para explorar cuáles variables ambientales explican mejor el patrón de asociación en la distribución espacial observada para las especies de murciélagos. En las 21 cuevas muestreadas se encontraron 23 especies de murciélagos, que corresponden al 32\% de la quiropterofauna de Jalisco (seis de ellas identificadas mediante llamados ultrasónicos). El análisis de ordenación NMDS separó las especies en tres grupos de especies que habitan las cuevas: calientes y húmedas, frescas y secas, y de gran altitud, asociada a hábitats templados. La temperatura y humedad fueron las variables ambientales más importantes para algunos grupos de murciélagos, y en otros fue la altitud. La riqueza y la abundancia de murciélagos varió entre cuevas y se asocian a los requerimientos propios de cada especie, las condiciones físicas particulares de cada cueva y el grado de perturbación humana que presentan. La asociación entre los factores ambientales, la presencia y abundancia de las especies de murciélagos fue estadísticamente significativa, sobre todo con la temperatura y humedad en el caso de las cuevas calientes; otras especies estuvieron asociadas principalmente con la altitud. Este estudio contribuye con datos útiles para ser utilizados como una línea de base respecto a los murciélagos cavernícolas en el Estado de Jalisco. Algunas de las cuevas deben ser consideradas prioritarias en términos de conservación, tanto por la cantidad de individuos, como por su riqueza específica.

Keywords: abundance; bat roosts; distribution; environmental variables; richness.

(C) 2018 Asociación Mexicana de Mastozoología, www.mastozoologiamexicana.org 


\section{Introduction}

Bats (order Chiroptera) represent the second most diverse order of mammals of the world in terms of number of species; there are more than 1,300 species of bats worldwide arranged in 20 families (Fenton and Simmons 2015). In Mexico, bats comprise 139 species, thus $10.7 \%$ of the chiropteran richness of the entire world is present in this country (Álvarez-Castañeda et al. 2015). This represents one of the richest bat faunas in the world (Ceballos and Oliva 2005). In the State of Jalisco bats comprise 72 species, which represent $41.9 \%$ of the mammals in the State (Iñiguez-Dávalos and Santana 2004). In Mexico, at least 60 out of the 139 species of bats so far described use caves as the first alternative for roosting, while in Jalisco 39 species are considered cave-users (Arita 1993; Iñiguez-Dávalos and Santana 2004).

Roosts are a key resource for bats because they pass at least half of their life in these sites. Bats use a great variety of roosts such as trees, hollow trunks, crevices, abandoned houses, among others; however, many of them use caves as roost sites (Villa-R. 1966; Kunz 1982; Kunz and Lumsden 2003). The use of cave roosts by bats is important to them to optimize some physiological, physical and ecological processes. Factors such as temperature, relative humidity, air flux, light intensity, safety against predators, proximity to foraging areas and fly height are important for bats not only for daily activity, but also for reproduction, parental care and mutual grooming (Altringham 1996; Kunz and Parsons 2009). Adequate microclimate can minimize the energetic cost related with thermoregulation, gestation, embrionary development, parental care, lactancy and social interaction (Kunz 1982; Altringham 1996; Cano-Santana and Martínez-Sánchez 1999; Avila-Flores and Medellín 2004; Tuttle and Moreno 2005; Torres-Flores et al. 2012; Luo et al. 2013). Some caves and mines contain the highest concentrations of mammals in the world. For example, at least 30 species of Latin America bats form colonies roosts in caves, and 24 of those had colonies with thousands to hundreds of thousands individuals (Tuttle et al. 2000). Therefore, for many species of bats, the conservation of cave environments is fundamental for its survival.

The State of Jalisco is located in the biogeographic transition between the Neartic and the Neotropic regions, allowing a mixture of species that belongs to both realms. Among the mammals of Jalisco, the order Chiroptera is the most diverse with 72 species classified in seven trophic guilds: aerial insectivore (41 species), frugivore (12), nectarivore (9), substrate insectivore (known also as gleaner) (6), omnivore (2), sanguinivore (1) and piscivore (1) (IñiguezDávalos and Santana C. 1993; Iñiguez-Dávalos and Santana 2004). In the case of insectivore bats, the classification has been more developed in function of the use of the ultrasonic calls related with the habitat structure (Schnitzler and Kalko 2001) and the type of prey being consumed (Segura-Trujillo et al. 2016).
While in the State of Jalisco there is a potential list of bat species that can be found in caves as well as in similar habitats, there are not accurate records of those species living in caves, neither the status of their colonies. The only recent work on cave bats in Jalisco describes basically the presence of five species in seven caves and a man-made tunnel; however, this study does not provide enough information about which species are present in each roost, neither an estimation of their abundance on them (Segura-Trujillo and Navarro-Pérez 2010). The aims of this study were to identify some of the main cave roosts for bats in the State of Jalisco, describe the richness and composition of bat ensembles associated to caves in our study area, and link the distribution and abundance of bats among caves with environmental factors.

\section{Materials and methods}

Study area. The study area corresponds to the State of Jalisco; we cover an altitudinal range from the sea level, the lowest cave visited, to 1,900 masl, the highest cave visited; from September 2010 to October 2011 we visited 21 caves with presence of bats (Figure 1). For purposes of this work, we refer as caves to both natural and some man-made cavities, because they share most of the physical characteristics, except the origin. Most of these caves are located in four main ecosystem types: Tropical deciduous forest, tropical sub-deciduous forest, pine-oak forest and pine forest, plus two area types without natural vegetation: beach and urban area. To identify and locate each of the 21 caves, in addition to a bibliographic survey, we asked to people involved in exploration and research on caves, such as researchers, speleologists, and local people from the towns near the caves of known location.

Field sampling. The number of bats per cave was assessed by direct observations or by reviewing photographs and videos taken into each cave roost; when the number of individuals into the cave was low. We carried out direct counts or we gauged the perching surface covered by bats. In order to use abundance of bats instead of direct count values during the multivariate analysis, we classify the estimated populations in four logarithmic categories: 1 ) less than 100 individuals, 2) between 100 and $1,000,3$ ) between 1,000 and 10,000 , and 4) more than 10,000 (Arita 1993).

To identify the presence of bats in each roost, we used two approaches: internal inspections, including the specific search of bats and their signs (feces, noise, dead bodies), and external inspections, using the observation and capture of bats outside the cave (Altringham 1996; Kunz and Parsons 2009). To capture bats, we used several techniques such as manual nets, mist nests and harp traps, according to the cave conditions, difficulty of capture and the number of bats in the roost (Kunz 1982). Also, when it was not possible to capture individuals, ultrasonic recordings were conducted using a Pettersson 240x bat detector in particular to register the presence of insectivorous bats, 


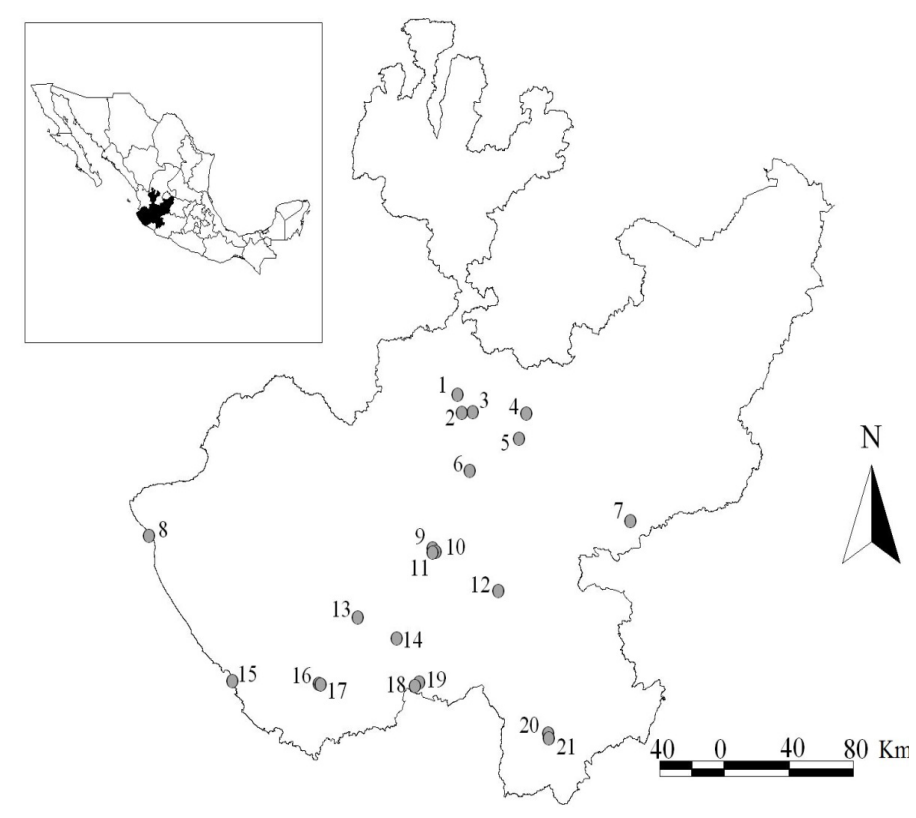

Figure 1. Location of the surveyed caves with bats. 1- Cueva Cuata, 2- Qanat Chimulco, 3- Grieta Tepetates, 4- Cueva San Bernardo, 5- Qanat Colomos, 6- Cueva Chapuzón, 7- Cueva de Toscano, 8- Cueva Tlalpichichi, 9- Cueva La Campana, 10- Cueva Bandoleros, 11- Cueva Paso Real, 12- Cueva Enamorados, 13- Mina San Francisco, 14Mina Cucuciapa, 15-Cueva Don Pancho, 16- Cueva Altilte, 17-Cueva del Diablo, 18-Cueva Resumidero de Toxín, 19-Cueva Torrecillas, 20- Cueva del Real, 21- Cueva Higuerilla.

which are difficult to survey by other techniques. These data were processed with the software SonoBat 3.1.

Captured bats were identified and their basic measurements were taken, subsequently they were released; we did not collect voucher specimens. To carry out the identification, we use the field key of Medellín et al. (2008), and the descriptions of Ceballos and Oliva (2005), plus the revision of specimens at the Vertebrate Collection of the Instituto Manantlán de Ecología y Conservación de la Biodiversidad, University of Guadalajara. In the case of the ultrasonic calls, they were identified visually and using the parameters obtained with the software SonoBat 3.1 (e.g. minimal and maximum frequencies, highest intensity frequency, duration of the call, interval between calls) and comparing them with reference collections (Sierra de Manantlán Biosphere Reserve, and Western México, unpubl. data) and published data (O'Farrel and Miller 1999; Schnitzler and Kalko 2001; Rydell et al. 2002; Jung et al. 2007, 2014; Orozco-Lugo et al. 2017). In each of the caves, we registered the basic physical measurements: temperature and relative humidity, with a termohigrometer HR656. The device was used to register different conditions while the cave was explored. However, the calls used for the data analysis were registered in the centre of the main chamber where the bats were roosting. The caves were described following the standard speleological techniques, including rock type, map of the cave, topography and roost characterization (Geze 1968; Arita 1993; Martínez-Hernández 2004). This data will be published in another work.

Regarding temperature and relative humidity inside the caves, they were classified in four environmental situations (Vargas-Contreras 1998), considering high or low tempera- ture, and dry or humid relative humidity conditions. Geographically, these caves are mostly in warm environments, so we select $22^{\circ} \mathrm{C}$ as the limit between low and high temperature inside the caves; for relative humidity, the cut was at $45 \%$. Therefore, we have dry $\left(>22{ }^{\circ} \mathrm{C}\right.$ and $\left.<45 \% \mathrm{HR}\right)$ or humid hot caves $\left(>22{ }^{\circ} \mathrm{C}\right.$ and $\left.>45 \% \mathrm{HR}\right)$, and dry $\left(<22^{\circ} \mathrm{C}\right.$ and $<45 \% \mathrm{HR})$ or humid fresh caves $\left(<22^{\circ} \mathrm{C}\right.$ and $\left.>45 \% \mathrm{HR}\right)$.

Data analysis Non-metric Multidimensional Scaling. To identify if there were association patterns among bat species found in the 21 caves, Non-metric Multidimensional Scaling analysis (NMDS) was conducted (PC-ORD v.5.1). NMDS is an indirect, non-linear, heuristic, ordination method that seeks to arrange samples (in the case of this investigation, caves based on bat species), so that each pair of caves is in a rank-order according to their dissimilarity. The graphical display provided by NMDS enables the data analyst to literally "look" at the data and to explore and interpret their structure visually (Clarke 1993). One of the advantages of this method is its flexibility to analyze data with a no-normal distribution or those that have a discontinuous or arbitrary scale. After several automatized runs, in order to identify the number of dimensions with the standardized residual sum of squares (stress), the program was used manually, with the following protocol: Distance measurement applied: Sorensen; number of axis: three; number of real data runs: 50 ; stability criteria: 0.00001 ; iterations to evaluate stability: 15; maximum iterations number: 250; length of the initial step: 0.20 . Also, Monte Carlo permutation tests were applied in each NMDS to determine if stress reductions were greater than expected when the data were analyzed randomly. The stress value ranges between 0 and 100; according McCune and Grasse (2002), a value ranging from 0 to 20 represents a good adjustment.

Canonical correspondence analysis. We then used Canonical Correspondence Analysis or CCA (PC-ORD v. 5.1) in order to identify the most important environmental variables that explain the bat species distribution in each of the sampled caves. For this aim we used as the main matrix the 21 caves and 23 species and as the secondary matrix, the 21 sites and seven environmental variables: altitude of the cave (ALT), length of the cave, measured using the traditional speleological techniques (compass, measuring tape and clinometers) (LAR), interior temperature (TEM), interior humidity (HUM), distance to the nearest open water sources, using a GPS and topographic maps (DIAG), number of species in the roost (ESP) and number of estimated individuals living in the roost (IND).

\section{Results}

Species richness. From September 2010 to October 2011, for all the 21 caves, we carried out two visits to each one trying to cover at least one in the dry season, and the other in the rainy season. We complete a total of 82 hours/net, 235 minutes of video and 120 minutes of audio (expanded time mode - 10x). We captured 452 bats. 
Twenty-three bat species were captured and identified, belonging to six families: Emballonuridae (1 species), Mormoopidae (4), Phyllostomidae (10), Natalidae (1), Vespertilionidae (6) and Molossidae (1). The Phyllostomidae family was represented by four subfamilies: Phyllostominae (1), Glossophaginae (5), Stenodermatinae (3) and Desmodontinae $(1 ;$ Table 1 , Appendix 1). Also, we recorded several echolocation calls; they were identified as representing six species, adding one species to the list. The species are included in six trophic guilds: aerial insectivores, gleaners, sanguinivores, frugivores, omnivores and nectarivores. Three of the captured species are included in the Mexican official list NOM-059-SEMARNAT-2010 as threatened (A) or under special protection (Pr): Leptonycteris yerbabuenae (Pr), L. nivalis (A), and Choeronycteris mexicana (A); two are endemic to Mexico: Corynorhinus mexicanus and Rhogeessa parvula (SEMARNAT 2015). According the red list of the IUCN, one species is endangered (L. nivalis), and three are near threatened: L. yerbabuenae, Ch. mexicana and C. mexicanus.

Sixteen species use only caves as roosts, while other seven use them regularly, but they can use another roosts as alternatives. According to its incidence (the potential to share roosts with other species, following Arita 1993), ten species are integrationists, with tendency to occupy caves with high richness; eight species are segregationists, with tendency to use caves with a few or no other species; and five are indifferent, without any apparent preference for low or high richness in the cave (Table 1).

Surveyed caves. The caves that were explored in this study are described briefly here. Both the physical and environmental data, as well as the estimation of richness and general abundance for each cave are summarized in Tables 2 and 3, respectively, and in the Appendix 1.

Cuata cave $\left(20^{\circ} 55^{\prime} \mathrm{N},-103^{\circ} 45^{\prime} \mathrm{W}\right)$. This cave is of volcanic origin, a lava shaped tube. This cave harbors three species of bats, in two families: Balantiopteryx plicata (Emballonuridae), Artibeus jamaicensis and Desmodus rotundus (Phyllostomidae). The estimated number of individuals from all species was 130. The cave is of difficult access, so the human activity is low, both inside and in the surroundings.

Chimulco qanat $\left(20^{\circ} 49^{\prime} \mathrm{N},-103^{\circ} 39^{\prime} \mathrm{W}\right)$. This is a manmade cave, built as an aqueduct. It harbors two species of the Phyllostomidae family: Desmodus rotundus and Glossophaga soricina. The total number of individuals living in the tunnel was 35 . Human disturbance is low, as this structure is inside a private property with restricted access.

Tepetates crevice, also known as Mosquitos cave $\left(20^{\circ} 49^{\prime}\right.$ $\mathrm{N}, 103^{\circ} 39^{\prime} \mathrm{W}$ ). This is a small crevice located in the wall of the Santiago river canyon. It harbors four species in two families: Balantiopteryx plicata (Emballonuridae), Artibeus jamaicensis, Desmodus rotundus and Glossophaga soricina (Phyllostomidae). The estimated number of individuals for all the species was 120 . The human disturbance is minimal.

San Bernardo cave $\left(20^{\circ} 49^{\prime} \mathrm{N},-103^{\circ} 20^{\prime} \mathrm{W}\right)$. This is a cave formed by the crevices of former landslides in the Barranca
Table 1. List of 23 bat species captured in 21 caves of Jalisco. Categories of cave use and incidence follow Arita (1993). Cave use: $\operatorname{Pr}=$ Principal, Al = Alternative. Incidence: I = Integrationist, $\mathrm{S}=$ Segregationist, IN = Indifferent. Trophic guild: $\mathrm{IA}=$ Aerial insectivore, $\mathrm{GL}=$ Gleaner, $\mathrm{NE}=$ Nectarivore, $\mathrm{FR}=$ Frugivore, $\mathrm{OM}=$ Omnivore, $\mathrm{SA}=$ Sanguinivore . Conservation categories: NOM-059-2010: $\mathrm{A}=$ Threatened; UICN: EN = Endangered, NT = Near threatened. Number of caves used (NC), cave use (CU), incidence (Inc), trophic guild (Tg), NOM-059-2010 (NOM).

\begin{tabular}{|c|c|c|c|c|c|c|c|}
\hline Family & Species & NC & cu & Inc & $\mathrm{Tg}$ & NOM & UICN \\
\hline Emballonuridae & Balantiopteryx plicata & 7 & $\operatorname{Pr}$ & $\mathrm{s}$ & IA & & \\
\hline \multirow[t]{4}{*}{ Mormoopidae } & Pteronotus davyi & 5 & $\operatorname{Pr}$ & 1 & IA & & \\
\hline & Pteronotus parnellii & 9 & $\operatorname{Pr}$ & 1 & IA & & \\
\hline & Pteronotus personatus & 4 & $\operatorname{Pr}$ & 1 & IA & & \\
\hline & Mormoops megalophylla & 7 & $\operatorname{Pr}$ & 1 & IA & & \\
\hline \multirow[t]{10}{*}{ Phyllostomidae } & Macrotus waterhousii & 1 & $\operatorname{Pr}$ & IN & $\mathrm{OM}$ & & \\
\hline & Glossophaga soricina & 9 & Al & 1 & NE & & \\
\hline & Leptonycteris yerbabuenae & 6 & $\operatorname{Pr}$ & 1 & NE & A & NT \\
\hline & Leptonycteris nivalis & 1 & $\operatorname{Pr}$ & 1 & NE & A & EN \\
\hline & Anoura geoffroyi & 1 & $\operatorname{Pr}$ & $\mathrm{s}$ & NE & & \\
\hline & Choeronycteris mexicana & 1 & $\operatorname{Pr}$ & IN & NE & A & NT \\
\hline & Sturnira parvidens & 2 & Al & $\mathrm{s}$ & FR & & \\
\hline & Artibeus jamaicensis & 9 & Al & IN & FR & & \\
\hline & Dermanura tolteca & 2 & $\mathrm{Al}$ & $\mathrm{s}$ & FR & & \\
\hline & Desmodus rotundus & 16 & $\operatorname{Pr}$ & IN & SA & & \\
\hline Natalidae & Natalus mexicanus & 5 & $\operatorname{Pr}$ & 1 & IA & & \\
\hline \multirow[t]{6}{*}{ Vespertilionidae } & Myotis velifer & 2 & $\operatorname{Pr}$ & IN & IA & & \\
\hline & Eptesicus furinalis & 2 & $\mathrm{Al}$ & 1 & IA & & \\
\hline & Eptesicus fuscus & 1 & Al & 1 & IA & & \\
\hline & Rhogeessa parvula & 2 & Al & S & IA & & \\
\hline & Corynorhinus mexicanus & 1 & $\operatorname{Pr}$ & $\mathrm{s}$ & GL & & NT \\
\hline & Corynorhinus townsendii & 1 & $\operatorname{Pr}$ & S & $\mathrm{GL}$ & & \\
\hline Molossidae & Tadarida brasiliensis & 4 & $\operatorname{Pr}$ & $\mathrm{s}$ & IA & & \\
\hline
\end{tabular}

of Huentitán, near Guadalajara. It harbors three species from two families: Choeronycteris mexicana and Desmodus rotundus (Phyllostomidae) and Corynorhinus townsendii (Vespertilionidae). The estimated number of individuals for all the species was 85 . This is a cave with a strong pressure from human activities, as is heavily visited by speleological groups.

Los Colomos qanat $\left(20^{\circ} 42^{\prime} \mathrm{N},-103^{\circ} 23^{\prime} \mathrm{W}\right)$. This is a man-made horizontal tunnel, it was used as an aqueduct and was built in pumice soil (igneous). It harbors four species in the family Phyllostomidae: Artibeus jamaicensis, Glossophaga soricina, Macrotus waterhousii and Sturnira parvidens. The estimated number of individuals for all the species was 45 . Although it is located in an urban park, the tunnel has low human disturbance, because the access is restricted with a gate.

Chapuzon cave $\left(20^{\circ} 33^{\prime} \mathrm{N},-103^{\circ} 41^{\prime} \mathrm{W}\right)$. This is a cave originated by water erosion on a volcanic fault. It harbors six species in three families: Pteronotus parnellii (Mormoopidae), Anoura geoffroyi, Artibeus jamaicensis, Desmodus 
rotundus, Leptonycteris yerbabuenae (Phyllostomidae), and Myotis velifer (Vespertilionidae). The estimated number of individuals for all the species was about 18,000 individuals. Human disturbance is moderated because the landowner normally does not accept visits to the cave.

Toscano's cave $\left(20^{\circ} 17^{\prime} \mathrm{N},-102^{\circ} 44^{\prime} \mathrm{W}\right)$. This is a crevice in the middle of the hill near Chapala Lake; part of the crevice is man-made, probably for mining purposes. It harbors three species of Phyllostomidae: Artibeus jamaicensis, Glossophaga soricina and Leptonycteris yerbabuenae. The estimated number of individuals for all the species was 200. This is a highly disturbed cave; we found many dead bats, and evidences of vandalism such as graffiti and trash.

Talpichichi cave $\left(20^{\circ} 14^{\prime} \mathrm{N},-105^{\circ} 34^{\prime}\right.$ West. This is a small cave located in a beach. It harbors three species in two families: Balantiopteryx plicata (Emballonuridae), Desmodus rotundus and Glossophaga soricina (Phyllostomidae). The estimated number of individuals for all the species was 30 . This cave has high human disturbance, because is visited by the tourists that go to the beach.

La Campana cave $\left(20^{\circ} 10^{\prime} \mathrm{N},-103^{\circ} 54^{\prime} \mathrm{W}\right)$. This is a cave located in a sedimentary canyon. It has six species, in two families: Pteronotus parnellii, P. davyi and P. personatus (Mormoopidae), and Leptonycteris yerbabuenae, Artibeus jamaicensis and Desmodus rotundus (Phyllostomidae). The estimated number of individuals from all species was 75,000 . Human disturbance is high, because this cave is frequently visited by excursionist groups.

Bandoleros cave $\left(20^{\circ} 09^{\prime} \mathrm{N},-103^{\circ} 54^{\prime} \mathrm{W}\right)$. It is located in the Ferreria river canyon. It harbors three species in three families: Desmodus rotundus (Phyllostomidae), Pteronotus parnellii (Mormoopidae) and Corynorhinus mexicanus (Vespertilionidae). The estimated number of individuals for all the species was 100. This cave is highly disturbed because is visited by speleologists and tourists; it is located near to a spa.

Paso Real cave $\left(20^{\circ} 09^{\prime} \mathrm{N},-103^{\circ} 54^{\prime} \mathrm{W}\right)$. This cave is in limestone at the fringe of the Ferrería stream. It harbors eight species in five families: Balantiopteryx plicata (Emballonuridae), Mormoops megalophylla, Pteronotus davyi (Mormoopidae), Artibeus jamaicensis, Desmodus rotundus, Glossophaga soricina (Phyllostomidae), Natalus mexicanus (Natalidae) and Rhogeessa parvula (Vespertilionidae). The estimated number of individuals for all the species was 6,000 . Disturbance is high, because the easy access it has; this cave is well known by speleologists. In the interior can be observed diggings and bags with guano.

Enamorados cave $\left(19^{\circ} 57^{\prime} \mathrm{N},-103^{\circ} 31^{\prime} \mathrm{W}\right)$. This is a small crevice in igneous rock. It harbors six species in two families: Balantiopteryx plicata (Emballonuridae), Artibeus jamaicensis, Dermanura tolteca, Desmodus rotundus, Glossophaga soricina and Sturnira parvidens (Phyllostomidae). The estimated number of individuals for all the species was 120 . Human disturbance is very high. There are smoke marks in the walls and roof, ash in the floor, and evidences of burned wood; according to local people, is burned regularly to "eliminate the vampires".
San Francisco mine $\left(19^{\circ} 50^{\prime} \mathrm{N},-104^{\circ} 20^{\prime} \mathrm{W}\right)$. This is a manganese mine that has been closed for a long time and has collapse risk. It harbors four species in two families: Mormoops megalophylla, Pteronotus parnellii (Mormoopidae), Leptonycteris yerbabuenae and Desmodus rotundus (Phyllostomidae). Also, has been reported the presence of Glossophaga sp. (González Ruvalcaba 2014). The estimated number of individuals for all the species was 4,500. Human disturbance is low, but the mining company is considering restarting its exploitation, which will affect the bats.

Cucuciapa mine $\left(19^{\circ} 44^{\prime} \mathrm{N},-104^{\circ} 07^{\prime} \mathrm{W}\right)$. This is an abandoned cooper mine, with several levels and high risk of collapses. It harbors six species in three families: Leptonycteris yerbabuenae (Phyllostomidae), Mormoops megalophylla, Pteronotus parnellii, P. personatus, P. davyi (Mormoopidae) and Natalus mexicanus (Natalidae). The estimated number of individuals for all the species was 35,000. This mine has minimal human disturbance because it is very dangerous and is located in a private farm.

Don Pancho cave $\left(19^{\circ} 32^{\prime} \mathrm{N},-105^{\circ} 05^{\prime} \mathrm{W}\right)$. This is a tectonic crevice open in igneous rock. It harbors six species in three families: Leptonycteris yerbabuenae (Phyllostomidae), Mormoops megalophylla, Pteronotus davyi, P. personatus, P. parnellii (Mormoopidae) and Natalus mexicanus (Natalidae). The estimated number of individuals for all the species was 100,000 . Human disturbance is low because it is located in an island one km away from the coast; however, inside, we found tools to extract guano from the cave.

Altilte cave $\left(19^{\circ} 31^{\prime} \mathrm{N},-104^{\circ} 34^{\prime} \mathrm{W}\right)$. This is a cave located in a limestone hill; it is considered a "hot cave". This cave harbors eight species of four families: Balantiopteryx plicata (Emballonuridae), Pteronotus parnellii, P. personatus, P. davyi, Mormoops megalophylla (Mormoopidae), Glossophaga soricina, Desmodus rotundus (Phyllostomidae) and Natalus mexicanus (Natalidae). The estimated number of individuals from all the species was 80,000 . In this cave, there are human disturbances regularly; inside we found tools for guano exploitation. However, the disturbance level in the surroundings is even higher, because in the same hill there is an active face for marble extraction; in this activity are used both heavy machinery and explosives.

Del Diablo cave $\left(19^{\circ} 31^{\prime} \mathrm{N},-104^{\circ} 34^{\prime} \mathrm{W}\right)$. It is found in a hill nearby the Altilte cave, also made of limestone. It harbors four species in two families: Balantiopteryx plicata (Emballonuridae), Artibeus jamaicensis, Desmodus rotundus and Glossophaga soricina (Phyllostomidae). The estimated number of individuals, including all species, was 70 . There were observed traces of human activity, and according to local people, they exploit the guano. Another important comment is that the number of bats was higher in the past, but suddenly they start to abandon this roost.

Resumidero de Toxin cave $\left(19^{\circ} 30^{\prime} \mathrm{N},-104^{\circ} 00^{\prime} \mathrm{W}\right)$. Is an active cave that has water inside all year long; is the longest cave known for the State of Jalisco. It harbors four species in three families: Desmodus rotundus (Phyllostomidae), Pterono- 
tus parnellii and Mormoops megalophylla (Mormoopidae), and Tadarida brasiliensis (Molossidae); the last three were identified using echolocation calls. The estimated number of individuals for all the species was 300 . It has low human disturbance, but is visited occasionally by speleologists.

Las Torrecillas cave $\left(19^{\circ} 31^{\prime} \mathrm{N},-103^{\circ} 59^{\prime} \mathrm{W}\right)$. This cave is in the upper part of the karstic dome named Cerro Grande, where is one of the few horizontal caves in this dome. It harbors eight species in four families: Tadarida brasiliensis (Molossidae), Eptesicus fuscus, Myotis velifer (Vespertilionidae), Mormoops megalophylla, Pteronotus parnellii (Mormoopidae), Dermanura tolteca, Desmodus rotundus and Leptonycteris nivalis (Phyllostomidae). The estimated number of individuals for all the species was 400 . It has low human disturbance because the cave is not widely known, even for local people.

Del Real cave $\left(19^{\circ} 16^{\prime} \mathrm{N},-103^{\circ} 13^{\prime} \mathrm{W}\right)$. This is a cave with two accesses and several passages. It harbors five species from four families: Desmodus rotundus (Phyllostomidae), Natalus mexicanus (Natalidae), Eptesicus furinalis and Rhogeessa parvula (Vespertilionidae), and Tadarida brasiliensis (Molossidae). Except for D. rotundus, all the species were identified using echolocation calls. The estimated total num-

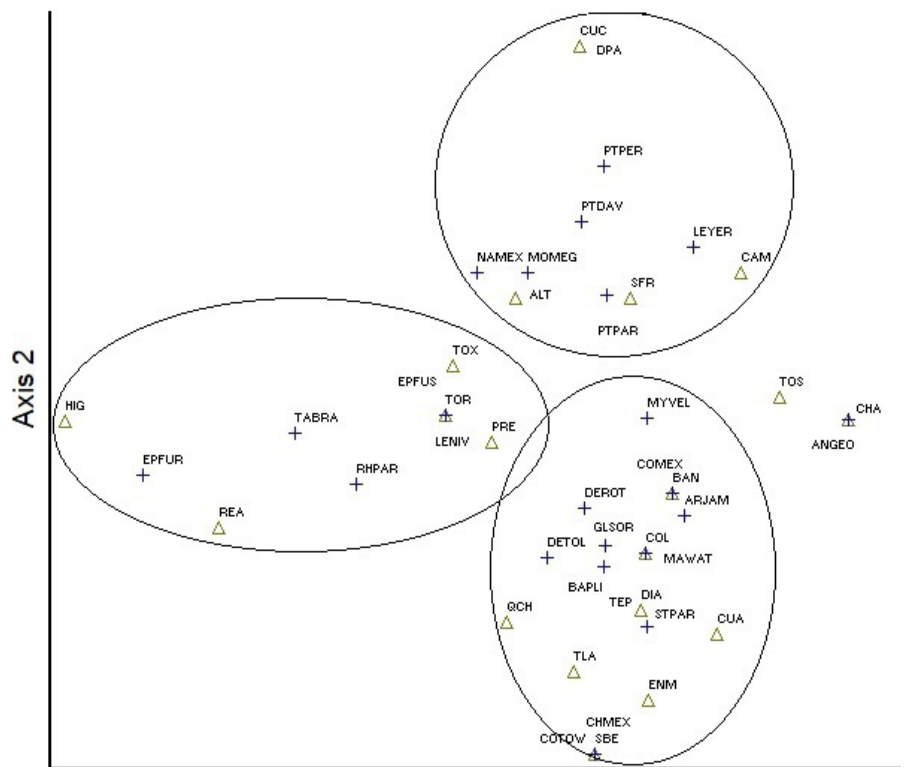

Axis 1

Figure 2. Non-metric Multidimensional Scaling analysis (NMDS), showing the first two axis for the whole dataset (21 caves $\times 23$ species) (stress 19.03; $p=0.04$ ). Triangles indicate the relative position of the caves in the axis, whereas the crosses indicate the relative position of the species (acronyms for bats and caves are in the appendix 2). The groups indicate caves that have similar composition of species.

ber of individuals was 40 . It has low human disturbance.

La Higuerilla cave $\left(19^{\circ} 14^{\prime} \mathrm{N},-103^{\circ} 13^{\prime} \mathrm{W}\right)$. This is mostly a vertical cave with a horizontal entrance. It harbors two species in two families, Eptesicus furinalis (Vespertilionidae) and Tadarida brasiliensis (Molossidae), both identified by echolocation calls. The estimated number of individuals was 20. Human disturbance is low.

Spatial relation among bats and caves. The NMDS analysis showed that three axes were enough to reliably explain the spatial distribution of bat species and their respective association with the sampled caves. The 23 species of bats were separated in three main groups. One group was positioned at the middle of the ordination diagram along axis one, whereas two groups were positioned along axis two of the ordination diagram (Figure 2; stress 19.03). The ordination diagram showed that one group was mainly represented by Mormoops megalophylla, Pteronotus davyi, $P$. parnellii, $P$. personatus, Natalus mexicanus and Leptonycteris yerbabuenae, which were associated to caves such as Altilte, Campana, Cucuciapa, Don Pancho, and San Francisco, most of them recognised as hot caves.

The second group which was positioned along axis two was mainly formed by Balantiopteryx plicata, Macrotus waterhousii, Glossophaga soricina, Choeronycteris mexicana, Artibeus jamaicensis, Sturnira parvidens, Desmodus rotundus, Myotis velifer, Corynorhinus mexicanus and C. townsendii; these species were linked to caves such as Bandoleros, Cuata, Diablo, Enamorados, Qanat Chimulco, Quanat Colomos, San Bernardo, Tepetates and, Tlalpichichi, all of them identified as cool caves.

The third group was formed by the species Leptonycteris nivalis, Eptesicus furinalis, E. fuscus, Rhogeessa parvula and Tadarida brasiliensis, found in the caves Del Real, Higuerilla, Paso Real, Resumidero Toxín and Torrecillas; it is important to remark that this last cave had the highest bat species richness in our study, and also has one the higher altitude

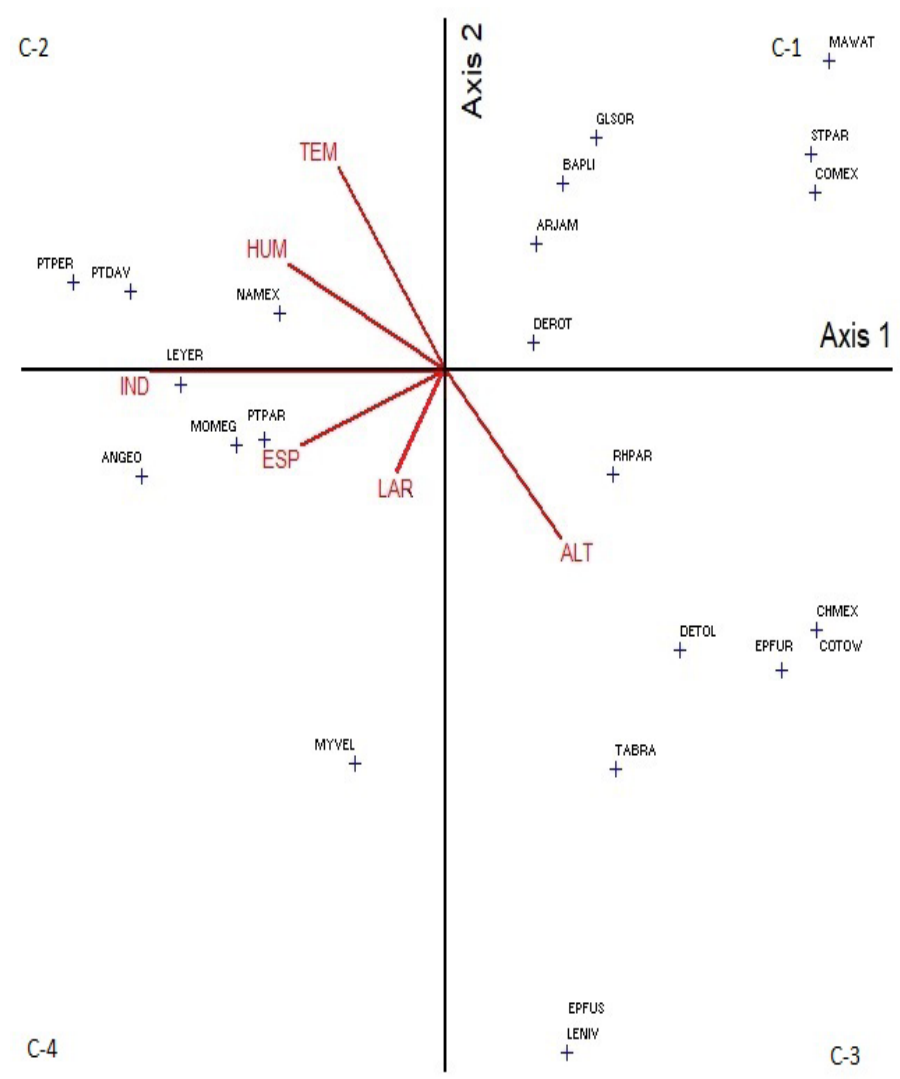

Figure 3. Canonical Correspondence Analysis (CCA) of environmental variables related with the bats species in 21 caves of Jalisco (acronyms for bats are in the appendix 2). The variables used in this analysis are: ALT- altitude, LAR- length of the cave, TEMtemperature, HUM- relative humidity, ESP- number of species, IND- number of individuals. 
Table 2. Physical and environmental data from the 21 sampled caves. Vegetation types surrounding the caves: TDF - Tropical deciduous forest, TSF - tropical sub-deciduous forest, POF - pine-oak forest, PF - pine forest, B - beach, UA - urban areas. Altitude in masl (Alt), Lenght of the cave in meters (LC), Temperature in ${ }^{\circ} \mathrm{C}\left({ }^{\circ} \mathrm{C}\right)$, percentaje of relative humidity (RH), Distance to a water source in meters (DW), Vegetation type (veg).

\begin{tabular}{|c|c|c|c|c|c|c|}
\hline Cave & Alt & LC & ${ }^{\circ} \mathrm{C}$ & (RH) & (DW) & Veg \\
\hline Cuata & 736 & 209 & 21 & 68 & 130 & TDF \\
\hline Qanat Chimulco & 1,263 & 47 & 34.5 & 88 & 0 & UA \\
\hline Tepetates & 1,309 & 37 & 26 & 36 & 275 & TDF \\
\hline San Bernardo & 1,195 & 370 & 19 & 31 & 1115 & TDF \\
\hline Quanat Colomos & 1,558 & 207 & 24 & 88 & 0 & PF \\
\hline Chapuzón & 1,407 & 623 & 18 & 41 & 0 & TDF \\
\hline Toscano & 1,644 & 115 & 27 & 44 & 730 & TDF \\
\hline Tlalpichichi & 8 & 17 & 30 & 80 & 2800 & B \\
\hline Campana & 1,290 & 460 & 18 & 62 & 215 & TSF \\
\hline Bandoleros & 1,264 & 620 & 24 & 41 & 8 & TDF \\
\hline Paso Real & 1,254 & 140 & 28 & 74 & 10 & TDF \\
\hline Enamorados & 1,385 & 12 & 22 & 43 & 150 & TDF \\
\hline San Francisco & 1,407 & 1,890 & 29 & 79 & 425 & TDF \\
\hline Cucuciapa & 1,006 & 75 & 26 & 86 & 370 & TDF \\
\hline Don Pancho & 3 & 65 & 31 & 91 & 1550 & TDF \\
\hline Altilte & 290 & 85 & 31 & 88 & 85 & TSF \\
\hline Del Diablo & 307 & 105 & 23 & 78 & 96 & TSF \\
\hline Resumidero Toxín & 1,201 & 3005 & 19.4 & 79 & 0 & TSF \\
\hline Torrecillas & 1,903 & 55 & 19 & 41 & 1500 & PF \\
\hline Del Real & 1,823 & 185 & 18 & 40 & 420 & PF \\
\hline Higuerilla & 1,806 & 47 & 24 & 38 & 1940 & POF \\
\hline
\end{tabular}

in our sample. The caves Toscano and Chapuzón, as well as the bat Anoura geoffroyi did form a small, isolated group along the axis one.

Bats and environmental variables relationship. The canonical correspondence analysis to explain the pattern of distribution of bats among caves showed that the most strongly weighed variables for the three first axes $\left(\lambda_{1}=0.472\right.$; $\lambda_{2}=0.310 ; \lambda_{3}=0.270$ ) were the number of individuals (IND), number of species (ESP) and relative humidity (HUM) along axis one, and interior temperature (TEM), altitude (ALT) and length of the cave (LAR) along axis two (Figure 3; Table 4). The CCA also corroborated the results of the NMDS; there is a group of bats, including mormoopids and natalids, with a tendency to live in hot and humid caves and other group associated with higher altitude caves.

\section{Discussion}

Within the 21 surveyed caves we found 23 bat species, which represents $40 \%$ of the total registered for the state. Our results also showed that the surveyed caves are rather different among them, in both bat species richness and abundance. All this variation is closely linked to the environmental conditions of the caves, and the biological and ecological requirements of the bats of the region (Arita and
Vargas 1995; Torres-Flores et al. 2012). The richness in each cave ranged from two to eight species, with an average of 4.7 species per cave. At a national level, $80 \%$ of the caves are roosts for one to three species, and only $10 \%$ holds more than six species (Arita 1993; Ruiz-Castillo 2006). Arita (1996) reported an average of 3.28 species per cave in the Yucatán Peninsula. In our study the percentages were 28.6 $\%$ with two or three species and $38.1 \%$ with six or more species. We consider that these differences could be attributable to the scarcity of caves suitable for roosts. Due the geological history of the region, Western México has a small amount of karstic or limestone areas, compared with the Sierra Madre Oriental or the Yucatán Peninsula (Challenger 1998; Ferrusquía-Villafranca 1998; Schaaf 2002). Also, the lack of forests with big trees in the tropical areas of the state (mostly dominated by tropical deciduous forests with small trees) could reduce the availability of roosts in the vegetation (Challenger 1998; Durán et al. 2002). Another important factor to be analyzed is the conservation degree of vegetation around the roost; a well-preserved and heterogeneous habitat will provide resources for more species and individuals (Fenton 1997).

Some roosts had only a few dozens of bats whereas others contained more than 100,000 individuals. Although

Table 3. Estimated number of species and individuals of bats in the 21 caves surveyed in this study. Abundance ranks: less than 100 individuals (1), between 100 and 1,000 (2), between 1000 and 10,000 (3), more than 10,000 (4).

\begin{tabular}{|c|c|c|c|}
\hline Cave & $\begin{array}{c}\text { Number of } \\
\text { species }\end{array}$ & $\begin{array}{l}\text { Estimated } \\
\text { abundance }\end{array}$ & $\begin{array}{c}\text { Ranked } \\
\text { abundance }\end{array}$ \\
\hline Don Pancho & 6 & 100,000 & 4 \\
\hline Altilte & 8 & 80,000 & 4 \\
\hline La Campana & 6 & 75,000 & 4 \\
\hline Cucuciapa & 6 & 35,000 & 4 \\
\hline Chapuzón & 6 & 18,000 & 4 \\
\hline Paso Real & 8 & 6,000 & 3 \\
\hline San Francisco & 4 & 4,500 & 3 \\
\hline Torrecillas & 8 & 400 & 2 \\
\hline Resumidero Toxín & 4 & 300 & 2 \\
\hline De Toscano & 3 & 200 & 2 \\
\hline Cuata & 3 & 130 & 2 \\
\hline Enamorados & 6 & 120 & 2 \\
\hline Grieta Tepetates & 4 & 120 & 2 \\
\hline Bandoleros & 3 & 90 & 1 \\
\hline San Bernardo & 3 & 85 & 1 \\
\hline Del Diablo & 4 & 70 & 1 \\
\hline Colomos & 4 & 45 & 1 \\
\hline Del Real & 5 & 40 & 1 \\
\hline Qanat Chimulco & 2 & 35 & 1 \\
\hline Tlalpichichi & 3 & 30 & 1 \\
\hline Higuerilla & 2 & 20 & 1 \\
\hline
\end{tabular}

$24 \%$ of our samples are caves with more than 10,000 bats, some caves showed evidences that in the past they housed larger populations than those registered during our fieldwork. For example, Cueva Del Diablo is a big cave with few species and small bat populations. Several evidences, 
which include the amount of guano, the presence of skeletons, plus observations of local people, suggest that in the past this roost was used by larger colonies. Although we have observed that bat abundance varies seasonally in many of the roosts we surveyed (unpubl. data), this was not the case of this cave; possibly the effect of habitat modification (agriculture, cattle) and human disturbance (visitors, guano extraction) had a rather negative impact in this cave.

The NMDS analysis, discerned three well-defined groups each with very distinct characteristics. The first group is mainly formed by species considered by Arita (1993) as integrationists, with preference for humid and hot caves; this group was represented by the families Mormoopidae and Natalidae, and the phyllostomid Leptonycteris yerbabuenae (Arita and Vargas 1995; Avila-Flores and Medellín 2004). Torres Flores et al. (2012) and Vargas Contreras et al. (2012) found a similar composition in the caves El Salitre, located in the State of Colima, and El Volcán de los Murciélagos, in the State of Campeche, respectively. An exception to this species composition was El Chapuzón cave, where we found a large colony of Leptonycteris yerbabuenae, but the temperature of the roost was cooler than in others $\left(18^{\circ} \mathrm{C}\right.$ to $24^{\circ} \mathrm{C}$ ); this cave seems to be used on a more temporary basis, likely between migrating movements (unpubl. data).

The second group is formed by species considered as generalists in terms of roost selection (Figure 3, C-1). These species are well adapted to live in caves with a wide range of environmental conditions, and can share or not, the use of roosts with other species (classified as indifferent ones by Arita 1993). Therefore, they can easily move to other roosts with similar or different environmental conditions (Arita 1993; Avila-Flores and Medellín 2004). This group includes species found in a higher number of caves: $D$. rotundus, $A$. jamaicensis and G. soricina. The third group was formed by species associated with high altitude caves and linked to temperate forests, as the Torrecillas cave; this cave had one of the highest species richness, although the abundance was comparatively low for all the species registered in this cave. Three of the species were found only at this roost: Leptonycteris nivalis, Eptesicus fuscus and Tadarida brasiliensis; also, Myotis velifer and Dermanura tolteca, both associated to temperate habitats. Vargas-Contreras (1998) found that microclimatic factors had influence in roost selection as well as the altitudinal gradient.

The CCA results suggest that the most important environmental variables to define groups were number of individuals living in the cave, temperature, relative humidity and altitude. Thus, the families Mormoopidae and Natalidae, plus the phyllostomids Leptonycteris yerbabuenae and Anoura geoffroyi, were highly associated with the first three environmental variables; these associations have been well documented in other regions of Mexico (Arita and Vargas 1995; Avila-Flores and Medellín 2004; Torres-Flores et al. 2012). A number of species were positively related to altitude, and hence with temperate habitats; this includes species such as Eptesicus fuscus, E. furinalis, Myotis velifer,
Rhogeessa parvula, Corynorhinus townsendii, Choeronycteris mexicana, Leptonycteris nivalis, Dermanura tolteca and Tadarida brasilensis. Finally, the last group was formed by species (mostly phyllostomids) that could be considered generalists and not associated directly with any of the analyzed variables, such as Artibeus jamaicensis, Desmodus rotundus, Glossophaga soricina, Sturnira parvidens, Macrotus waterhousii, Balantiopteryx plicata and Corynorhinus mexicanus. A number of authors (e. g., Fenton et al. 1992; Medellín et al. 2000) have pointed out that these species are considered as indicators of habitats associated to human disturbances. That could be the case with our data, where the most disturbed caves had some of these species, yet usually in low abundances; however, C. mexicanus could be more associated with altitude (Tumlinson 1992), so we consider that probably this species was underrepresented in our sample.

This study contributes with useful data, which could be used as baseline for cave bats research not only for the State of Jalisco, but also for other latitudes with presence

Table 4. Statistical values for each ordination axis in the Canonical Correspondence Analysis.

\begin{tabular}{lccc}
\hline & \multicolumn{3}{c}{ Axis } \\
& 1 & 2 & 3 \\
\hline Eigenvalues & 0.472 & 0.310 & 0.270 \\
& & & \\
Variance in the species data & & & \\
\% of explained variance & 12.0 & 7.9 & 26.7 \\
$\begin{array}{l}\text { Accumulated } \\
\text { Total variance ("inertia") } \\
\text { in the species data }\end{array}$ & 12.0 & 19.8 & 3.943 \\
\hline
\end{tabular}

of these important mammals. Some of the surveyed roosts are relevant in terms of priority for conservation, in particular those with a large number of individuals (Altilte, Campana, Chapuzón, Cucusiapa and Don Pancho) or with high species richness (Altilte, Paso Real and Torrecillas caves; Arita 1993; Luo et al. 2013; Medellín 2017). Presence of threatened or endemic species must be considered; these features highlights the importance to preserve also small or low richness caves, independently of their environmental attributes (Bandoleros, Del Real, Paso Real and San Bernardo) if they harbors other relevant species (Arita 1993; Fenton 1997; Luo et al. 2013).

\section{Acknowledgements}

We thank the support of the Mexican National Council of Science and Technology (CONACYT) for the support of this work through the Ph.D. scholarship no. 222308 to HLAT. This study is part of the program Doctorate in Biosystematics, Ecology, and Natural and Agricultural Resources Management of the University of Guadalajara. We thank to biology students Jose Luis de Luna-Ornelas, Carolina Magaña-González and Gustavo Padilla-Cárdenas, for their help in the field. 


\section{References}

Altringham, J. 1996. Bats: Biology and behavior. Oxford University Press. New York, U. S. A.

Álvarez-Castañeda, S. T., T. Álvarez, and N. González-Ruiz. 2015. Guía para la identificación de los mamíferos de México en campo y laboratorio. Centro de Investigaciones Biológicas del Noroeste and Asociación Mexicana de Mastozoología, A.C. La Paz, Baja California Sur, México.

ARITA, H. 1993. Conservation biology of the cave bats of México. Journal of Mammalogy 74:693-702.

ARITA, H. 1996. The conservation of cave-roosting bats in Yucatán, México. Biological Conservation 76:177-185.

ARITA, H., AND J. VARGAS. 1995. Natural history, interspecific association, and incidence of the cave bats of Yucatan, Mexico. Southwestern Naturalist 40:29-37.

Ávila-Flores, R., ANd R. Medelín. 2004. Ecological, taxonomic, and physiological correlates of cave use by Mexican bats. Journal of Mammalogy 85:675-687.

Cano-Santana, Z., and J. Martínez-Sánchez. 1999. Las cuevas y sus habitantes: Serie. La ciencia para todos 181. Consejo Nacional de Ciencia y Tecnología. Ciudad de México, México. Ceballos, G., And G. Oliva. 2005. Orden Chiroptera. Pp. 161337 in Los Mamíferos Silvestres de México (Ceballos, G., and G. Oliva, coords.). CONABIO, Fondo de Cultura Económica. Ciudad de México, México.

Challenger, A. 1998. Utilización y conservación de los ecosistemas terrestres de México: Pasado, presente y futuro. Comisión Nacional para el Conocimiento y Uso de la Biodiversidad (CONABIO). Ciudad de México, México.

ClaRkE, K. R. 1993. Non-parametric multivariate analyses of changes in community structure. Australian Journal of Ecology 18:117-143.

Durán, E., P. Balvanera, E. Lott, G. Segura, A. Pérez-Jiménez, A. Islas, and M. Franco. 2002 Estructura, composición y dinámica de la vegetación. Pp. 443-472 in Historia Natural de Chamela (Noguera, F. A., J. H. Vega Rivera, A. N. García Aldrete, and M. Quesada Avendaño, eds.). Instituto de Biología, Universidad Nacional Autónoma de México. Ciudad de México, México.

Fenton, M. B., L. Acharya, D. Audet, M. B. Hickey, C. MerRiam, M. K. Obrist, D. M. SYME, AND B. AdkINS. 1992. Phyllostomid bats (Chiroptera: Phyllostomidae) as indicators of habitat disruption in the Neotropics. Conservation Biology 14:1666-1675.

FEnton, M. B. 1997. Science and the conservation of bats. Journal of Mammalogy 78:1-14.

Fenton, M. B., AND N. B. Simmons. 2015. Bats: a world of science and mystery. University of Chicago Press. Chicago, U. S. A.

Ferrusquía Villafranca, I. 1998. Geología de México: una sinopsis. Pp. 3-108 in Diversidad biológica de México: Orígenes y distribución (Ramamoorthy, T. P., R. Bye, A. Lot, and J. Fa, eds.). Universidad Nacional Autónoma de México. Ciudad de México, México.

GezE, B. 1968. La espeleología científica. Ediciones Martínez Roca. Barcelona, España.

González Ruvalcaba, S. 2014. Presencia de algunos patógenos en murciélagos del occidente de Jalisco. Maestría en Manejo de Recursos Naturales. Centro Universitario de la Costa Sur, Universidad de Guadalajara. Autlán, Jalisco, México.
Iñiguez-Davalos, L. I., and E. Santana. 1993. Patrones de distribución y riqueza de especies de los mamíferos del occidente de México. Pp. 65-86 in Avances en el estudio de los mamíferos de México (Medellín, R., and G. Ceballos, eds.). Publicación Especial, Vol. 1. Asociación Mexicana de Mastozoología, A. C. Ciudad de México, México.

IÑIGUez-DAvalos, L. I., AND E. Santana. 2004. Análisis mastofaunístico del Estado de Jalisco. Pp. 251-258 in Contribuciones mastozoológicas en homenaje a Bernardo Villa (SánchezCordero V., and R. A. Medellín, eds.). Instituto de Biología and Instituto de Ecología, UNAM. Ciudad de México, México.

JunG, K., E. K. V. KalKo, AND O. von Helversen. 2007. Echolocation calls in Central America emballonurid bats: signal design and call frequency alternation. Journal of Zoology 272:125-137.

Jung, K., J. Molinari, and E. K. V. KalKo. 2014. Driving factors for the evolution of species-specific echolocation call design in new world free tailed bats (Molossidae). PLOS ONE 9:1-9.

Kunz, T. H. 1982. Roosting ecology of bats. Pp 1-55 in Ecology of Bats (Kunz, T. H., ed.). Boston University. Boston, U. S. A.

KUNZ, T. H., AND L. LUMSDEN. 2003. Ecology of cavity and foliage roosting bats. Pp 3-89 in Bat Ecology (Kunz, T. H., and B. M. Fenton, eds.). The University of Chicago Press. London, United Kindom.

Kunz, T. H., AND S. Parsons. 2009. Ecological and behavioral methods for the study of bats. The John Hopkins University Press. Baltimore, U. S. A.

LUO, J., T. JIANG, G. LU, L. WANG, AND J. FenG. 2013. Bats conservation in China: should protection of subterranean habitats be a priority? Oryx 47:526-531.

Martínez-HeRnández, J. 2004. Manual de espeleología. Manuales Desnivel. Ediciones Desnivel. Madrid, España.

McCunE, B., AND J. GRACE. 2002. Analysis of ecological communities. MjM Software design. Gleneden Beach, U. S. A.

Medellín, R. A., R. Wiederholt, and L. López-Hoffman. 2017. Conservation relevance of bat caves for biodiversity and ecosystem services. Biological Conservation 42:309-349.

Medellín, R. A., M. Equinua, ANd M. A. Amín. 2000. Bat diversity and abundance as indicators of disturbance in Neotropical rainforests. Conservation Biology 14:1666-1675.

Medellín, R. A., H. ARita, and O. Sánchez H. 2008. Identificación de los murciélagos de México. Clave de campo. Instituto de Ecología, Universidad Nacional Autónoma de México. Ciudad de México, México.

O'FARRELL, M. J., AND B. W.MILLER. 1999. Use of vocal signatures for the inventory of free-flying neotropical bats. Biotropica 31:507-516.

Orozco-Lugo, C. L., A. Guillén-Servent, D. Valenzuela-Galván, H. T. ARITA, AND N. A. Mariano-Bonigo. 2017. Variación espaciotemporal en la actividad relativa de murciélagos insectívoros aéreos en la Reserva de la Biosfera Sierra de Huautla, Morelos. Áreas Naturales Protegidas Scripta 3:37-57.

RuIZ-CASTILLO, A. 2006. Priorización de cuevas para la conservación de murciélagos cavernícolas de México. Tesis de maestría. Facultad de Ciencias, UNAM. Ciudad de México, México.

Rydell, J., H. T. Arita, M. Santos, and J. Granados. 2002. Acoustic identification of insectivorous bats (order Chiroptera) of Yucatán, México. Journal of Zoology 257:27-36.

SchaAf, P. 2002. Geología y geofísica de la costa de Jalisco. Pp. 11-18 in Historia Natural de Chamela (Noguera, F. A., J. H. Vega Rivera, A. N. García Aldrete, and M. Quesada Avendaño, eds.). Instituto de Biología, Universidad Nacional Autónoma de México. Ciudad de México, México. 
SChNitzleR, H. U., AND E. K. V. Kalko. 2001. Echolocation by insecteating bats: We define four distinct functional groups of bats and find differences in signal structure that correlate with the typical echolocation tasks faced by each group. BioScience 51:557-569.

Segura-Trujlllo, C. A., and S. Navarro-Pérez. 2010. Escenario y problemática de conservación de los murciélagos (Chiroptera) cavernícolas del Complejo Volcánico de Colima, Jalisco-Colima, México. Therya 1:189-206.

Segura-Trujlilo, C. A., W. Z. Lidicker JR., and S. T. Álvarez-Castañeda. 2016. New perspectives an trophic guilds of arthropodivorous bats in North and Central America. Journal of Mammalogy 97:644-654.

Semarnat (Secretaria del Medio Ambiente y Recursos Naturales). 2010. Norma Oficial Mexicana NOM-059-SEMARNAT-2010. Protección ambiental-Especies nativas de México de flora y fauna silvestres. Categorías de riesgo y especificaciones para su inclusión, exclusión o cambio. Lista de especies en riesgo. Diario Oficial de la Federación, 30 de diciembre de 2010. Ciudad de México, México.

Semarnat (Secretaría del Medio Ambiente y Recursos Naturales). 2015. Proyecto de Modificación del Anexo Normativo III, Lista de especies en riesgo de la Norma Oficial Mexicana NOM059-SEMARNAT-2010, Protección ambiental-Especies nativas de México de flora y fauna silvestres-Categorías de riesgo y especificaciones para su inclusión, exclusión o cambio-Lista de especies en riesgo, publicada el 30 de diciembre de 2010. Diario Oficial de la Federación, 21 de diciembre de 2015. Ciudad de México, México.

Simmons, N. B. 2005. Order Chiroptera. Pp. 312-529 in Mammal species of the world: a taxonomic and geographic reference. Volume 1 (D. E. Wilson, and D. M. Reeder, eds.). John Hopkins University Press. Baltimore, USA.

Torres-Flores, J., R. López-Wilchis, and A. Soto-Castruita. 2012. Dinámica poblacional, selección de sitios de percha y patrones reproductivos de algunos murciélagos cavernícolas en el oeste de México. Revista de Biología Tropical 60:13691389.

Tumlinson, R. 1992. Plecotus mexicanus. Mammalian Species 401:1-3.

TutTLE, D. M., AND A. Moreno. 2005. Murciélagos cavernícolas del norte de México. Bat Conservation International Inc. Austin, USA.

Tuttle, D. M., D. Taylor, R. A. Medellín, and S. Walker. 2000. Murciélagos y minas. Bat Conservation Inc. Austin, U. S. A.

Vargas-Contreras, J. A. 1998. Factores microclimáticos y selección del refugio diurno por murciélagos cavernícolas en Gómez Farías, Tamaulipas. Tesis de maestría, UNAM. Ciudad de México, México.

Vargas-Contreras, J. A., G. Escalona-Segura, J. D. Cú Vizcarra, J. Arroyo Cabrales, J. Rendón, And L. Navarro. 2012. Conservación de murciélagos en Campeche. Therya 3:53-66.

VILLA-R., B. 1966. Los murciélagos de México. Instituto de Biología, Universidad Nacional Autónoma de México. Ciudad de México, México. 


\section{Appendix 1.}

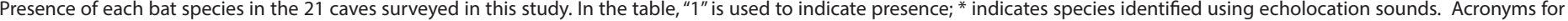
caves are in appendix 2 .

\begin{tabular}{|c|c|c|c|c|c|c|c|c|c|c|c|c|c|c|c|c|c|c|c|c|c|}
\hline \multirow[b]{2}{*}{ Species } & \multicolumn{21}{|c|}{ Caves } \\
\hline & $\stackrel{\circ}{\circ}$ & $\underset{\frac{\alpha}{\alpha}}{\breve{\alpha}}$ & 声 & ธิ & త્વ & $\sum_{\mathbb{\delta}}$ & ૫ & $\sum_{z}$ & $\underset{\widetilde{\varpi}}{\mathbb{\varpi}}$ & 㸓 & ્ㅗㅁ & $\overleftarrow{\Delta}$ & 站 & 어 & $\underset{\mathbf{\Phi}}{\mathbf{Z}}$ & 岗 & ํㅡㅁ & $\stackrel{\lessgtr}{\lessgtr}$ & 己 & 음 & İ \\
\hline Balantiopteryx plicata & & 1 & 1 & & & & & 1 & & & & 1 & 1 & & & & & 1 & 1 & & \\
\hline Pteronotus davyi & & 1 & 1 & 1 & & 1 & 1 & & & & & & & & & & & & & & \\
\hline Pteronotus parnellii & 1 & & 1 & 1 & 1 & 1 & 1 & & & 1 & $1^{*}$ & & & & 1 & & & & & & \\
\hline Pteronotus personatus & & & 1 & 1 & & 1 & 1 & & & & & & & & & & & & & & \\
\hline Mormoops megalophylla & 1 & 1 & 1 & 1 & & & 1 & & & 1 & $1^{*}$ & & & & & & & & & & \\
\hline Macrotus waterhousii & & & & & & & & & & & & & & 1 & & & & & & & \\
\hline Glossophaga soricina & & 1 & 1 & & & & & 1 & & & & 1 & 1 & 1 & & & 1 & 1 & & & 1 \\
\hline Leptonycteris yerbabuenae & & & & 1 & 1 & 1 & 1 & & & 1 & & & & & & & 1 & & & & \\
\hline Leptonycteris nivalis & 1 & & & & & & & & & & & & & & & & & & & & \\
\hline Anoura geoffroyi & & & & & 1 & & & & & & & & & & & & & & & & \\
\hline Choeronycteris mexicana & & & & & & & & & & & & & & & & 1 & & & & & \\
\hline Sturnira parvidens & & & & & & & & 1 & & & & & & 1 & & & & & & & \\
\hline Artibeus jamaicensis & & 1 & & & 1 & 1 & & 1 & & & & 1 & 1 & 1 & & & 1 & & 1 & & \\
\hline Dermanura tolteca & 1 & & & & & & & 1 & & & & & & & & & & & & & \\
\hline Desmodus rotundus & 1 & 1 & 1 & & 1 & 1 & & 1 & 1 & 1 & 1 & 1 & 1 & & 1 & 1 & & 1 & 1 & & 1 \\
\hline Natalus mexicanus & & 1 & 1 & 1 & & & 1 & & $1^{*}$ & & & & & & & & & & & & \\
\hline Myotis velifer & 1 & & & & 1 & & & & & & & & & & & & & & & & \\
\hline Eptesicus furinalis & & & & & & & & & $1^{*}$ & & & & & & & & & & & $1^{*}$ & \\
\hline Eptesicus fuscus & 1 & & & & & & & & & & & & & & & & & & & & \\
\hline Rhogeessa parvula & & 1 & & & & & & & $1^{*}$ & & & & & & & & & & & & \\
\hline Corynorhinus mexicanus & & & & & & & & & & & & & & & 1 & & & & & & \\
\hline Corynorhinus townsendii & & & & & & & & & & & & & & & & 1 & & & & & \\
\hline Tadarida brasiliensis & 1 & & & & & & & & $1^{*}$ & & $1^{*}$ & & & & & & & & & $1^{*}$ & \\
\hline Total of species per cave & 8 & 8 & 8 & 6 & 6 & 6 & 6 & 6 & 5 & 4 & 4 & 4 & 4 & 4 & 3 & 3 & 3 & 3 & 3 & 2 & 2 \\
\hline
\end{tabular}


Appendix 2.

Acronyms for the species of bats and the name of the caves.

\begin{tabular}{|c|c|c|c|c|c|}
\hline & Bat species & Acronym & & Cave name & Acronym \\
\hline 1 & Balantiopteryx plicata & BAPLI & 1 & Cuata & CUA \\
\hline 2 & Pteronotus davyi & PTDAV & 2 & La Campana & CAM \\
\hline 3 & Pteronotus parnellii & PTPAR & 3 & Altilte & ALT \\
\hline 4 & Pteronotus personatus & PTPER & 4 & Del Diablo & DIA \\
\hline 5 & Mormoops megalophylla & MOMEG & 5 & Paso Real & PRE \\
\hline 6 & Macrotus waterhousii & MAWAT & 6 & Chapuzón & $\mathrm{CHA}$ \\
\hline 7 & Glossophaga soricina & GLSOR & 7 & Enamorados & ENM \\
\hline 8 & Leptonycteris yerbabuenae & LEYER & 8 & San Bernardo & SBE \\
\hline 9 & Leptonycteris nivalis & LENIV & 9 & Cucuciapa & CUC \\
\hline 10 & Anoura geoffroyi & ANGEO & 10 & San Francisco & SFR \\
\hline 11 & Choeronycteris mexicana & CHMEX & 11 & Bandoleros & BAN \\
\hline 12 & Sturnira parvidens & STPAR & 12 & Torrecillas & TOR \\
\hline 13 & Artibeus jamaicensis & ARJAM & 13 & R. Toxin & TOX \\
\hline 14 & Dermanura tolteca & DETOL & 14 & Qanat Chimulco & $\mathrm{QCH}$ \\
\hline 15 & Desmodus rotundus & DEROT & 15 & Grieta Tepetates & TEP \\
\hline 16 & Natalus mexicanus & NAMEX & 16 & De Toscano & TOS \\
\hline 17 & Myotis velifera & MYVEL & 17 & Del Real & REA \\
\hline 18 & Eptesicus furinalis & EPFUR & 18 & Higuerilla & HIG \\
\hline 19 & Eptesicus fuscus & EPFUS & 19 & Tlalpichici & TLA \\
\hline 20 & Rhogeessa parvula & RHPAR & 20 & Don Pancho & DPA \\
\hline 21 & Corynorhinus mexicanus & COMEX & 21 & Colomos & $\mathrm{COL}$ \\
\hline 22 & Corynorhinus townsendii & cotow & & & \\
\hline 23 & Tadarida brasiliensis & TABRA & & & \\
\hline
\end{tabular}

